\title{
STUDY AND ANALYSIS OF EFFICIENCY INVESTMENT OF THE STREET LIGHT SYSTEM ON NATIONAL HIGHWAY 1, FROM THE JUNCTIONS, BEN CHUA BRIDGE TO TAN HIEP TOWN CENTRE, CHAU THANH DISTRICT, TIEN GIANG PROVINCE
}

\author{
Le Ngo Ngoc Thu', Vo Thi Thuy An ${ }^{2}$,Dang Hoang Ngoc Linh ${ }^{3}$ and Pham Duc Trung ${ }^{4}$ \\ ${ }^{1}$ Department of Airports - Vietnam Aviation Academy \\ ${ }^{2}$ Tien Giang Department of Transport \\ ${ }^{3}$ Wittenborg University - Netherlands \\ ${ }^{4}$ Ho Chi Minh City University of Resources and Environment(HCMUNRE)
}

http://doi.org/10.35409/IJBMER.2020.3172

\begin{abstract}
It perhaps true that development infrastructure is an important prerequisite condition for promoting socio-economic development. The building of asynchronous and modern domestic transport infrastructure system is to connect with the regional transport infrastructure which base on the reasonable use of resources for focused and key investment, in which prioritizing the construction of spillover works, ensuring the connection of modes of transport, major economic zones, key economic regions, gateways and important transport hubs in association with Transport infrastructure network in the region links is very necessary to be solved to show a strategic vision in the future. Through the cost and benefit analysis tools (CBA), his article will analyze the effectiveness of the benefits and costs of the street lighting system National Highway 1, from the junctions, Ben Chua bridge to Tan Hiep town centre, Chau Thanh district, Tien Giang province. As a result, some implications for managers in improving investment effectively will be proposed by the research team.
\end{abstract}

Keyword: Investment Efficiency, Street Lighting System On Nation Highway, Cost And Benefit Analysis.

\section{INTRODUCTION}

The National Highway 1 (NH1), the stretch of this road which is pass through Tien Giang province plays the key role for traffic in the Southwest region. From Ho Chi Minh City (HCMC) to Can Tho City or Vinh Long Province, Dong Thap, Kien Giang, An Giang, Ca Mau Province etc. and the opposite side, this road known as the road for people to go. Moreover, this NH1 is also well known as a critical transportation link promotes the exchange and support for economic development between two key economic zones and some provinces in the South of Vietnam together. Due to this National Highway, the entire Mekong Delta is more closely connected with Ho Chi Minh

City and some Southeast provincesto accelerate economic development - regional society in terms of international integration and contribute the great deal of benefits to the economy of this region and the whole country. 


\section{International Journal of Business Management and Economic Review}

Vol. 3, No. 02; 2020

ISSN: 2581-4664

It goes without saying that hazard and protection control for road users on all routes is extremely important and attracts the attention of society. A few years ago, although major transport projects invested by the Ministry of Transport, it is highly likely that the segment of transportation works of grades III-IV, technical infrastructure works related to traffic such as street lights, traffic lights, etc was drawn the big domestic investors' attention and approach. In fact, the distance from Luong Phu Crossroad to Tan Hiep town centre in Cha Thanh district, Tien Giang province, the traffic issue is extremely complicated which causes lots of traffic accidents (TA). The reason for this phenomenon can be attributed for the fact that this is the highest distance of NH1 which pass through some provinces of Mekong Delta and the other roads in Tien Giang and occupy a large kind of vehicles. It is necessary to install the street light (SLS) and vision support systems or road user. Moreover, if there is a case of suddenly broken vehicle on the road, the driver can easily observe and avoid the endanger accident. Investing in SLS on the road will help road users to be safer and safer, the traffic accidents will be minimized at the lowest level, and security and order situation will be guaranteed. Furthermore, it is common nowadays for the decision-makers to make policies aiming at promoting the development of transport infrastructure, while decision makers have to face with the consideration for two equal reasons between the price for the implementation and the benefits for from that policy. However, the reality shows that the decision-making of policymakers is an obstacle because of the qualitative or intuitive choices which require significant consideration of the costs and benefits in order to observe the net profit of decision making, or the effectiveness of those costs. CostBenefit Analysis (CBA) is a technical tool that demonstrates a quantitative calculation, converts all of costs and benefits into a unified unit of measurement - monetary value which is able to help the decision maker decide the better choice of public policy decision with the government's limited resources. The analysis of benefits - costs of investment projects, general analysis of economic benefits - economic costs of whole of society will determine exactly the efficiency of investment to support the research managers about the improvement of the quality of transport works.

From what above reasons, the authors conducted the study: analysis of efficiency investment of the street light system on national highway 1, from the junctions, Ben Chua bridge to Tan Hiep town centre, Chau Thanh district, Tien Giang province".

\section{SUBJECTS, METHOD AND DATA OF STUDY}

To study and analyze to determine mainly basic factors about investment efficient

It applies comparison method of datasheet, analysis of comparable statistic mainly basic factors about investment efficient index to achieve the study objectives.

\section{Sample and Design of Study}

To select and survey a sample size of 620 The street lighting system which are determined to mainly basic factors about investment efficient

\section{Scope of Study}

03 items of articles : the street lighting system National Highway 1

The street lighting system National Highway 1: from Chau Thanh district, Tien Giang province (Km 1961+400, Km1974+700, Km1979+000, Km1980+600, Km 1982+300)

The street lighting system National Highway 1 : from the junctions Lương Phu to Tan Hiep town $(\mathrm{Km} 1960+700$ to $\mathrm{Km} 1963+600)$ 


\section{International Journal of Business Management and Economic Review}

Vol. 3, No. 02; 2020

ISSN: 2581-4664

The street lighting system National Highway 1: from the junctions, Ben Chua bridge to Tan Hiep town centre $(\mathrm{Km} 1963+600$ to $\mathrm{Km} 1966+600)$

\section{RESULTS AND DISCUSION}

\section{Road traffic works}

Road works include roadside and parking spaces, signal light, signpost, road markings, cone, roadblock, centre divider, milestones, embankments, drainage systems, vehicle load checking stations, tollgates and other road auxiliary facilities and projects.

\section{Street light system}

The lighting system includes natural SLS and artificial SLS, in which artificial SLS includes light bulbs (fluorescent, incandescent, compact, LED, high pressure, etc.). Nowadays, street lighting often uses high-intensity discharge lamps, which occupy the main advantages of street lighting including accident prevention and increasing safety.

It is widely accepted that the convenient and effective SLS need to precise fulfilling user's requirements, high economic efficiency, environment preservation, suitable space and safty for road user.

\section{Cost-Benefit Analysis - CBA}

According to Boardman (1996): CBA (Cost-Benefit Analysis) is a method of evaluating monetary value of all results of policies for all of social classes. And net social benefits is a measure of policy value.

CBA analysis is a extensive technical term, however, it was limited to quantitative technical analysis for a project and to a restrictively geographical range as well as a certain time period in the previous period. Nevertheless, this term is seem to be more broadly developed to include two related concepts: financial analysis and economic analysis. Firstly, the financial analysis only involves cash inflows and cash outflows of investors, or this type of analysis is believed to base on personal opinion. Secondly, the economic analysis not only accounts the inflows and outflows of investors but also pays more attention to both negative and positive impacts on the environment and society, so this type of analysis is usually called that it based on social. In short, in term of CBA together, the financial analysis results distinguish with the economic analysis. In this study, the authors did not analyze project finance.

CBA always follows simple and continuous steps, in which whole of process is based on a scientifically problem-solving method. CBA consists of nine following steps:

Step 1: Identify the problem and determine solutions.

Step 2: Identify the costs and benefits of each option.

Step 3: Assess the benefits and costs of each option by monetary quantification.

Step 4: Discount the benefits and costs to back to the present price. Calculate the efficiency evaluation criteria. Convert the cost - benefit flows of present value.

Step 5: Determine the selection criteria of the project. Calculate the criteria to evaluate the effectiveness of each option which base on the project life-cycle.

Future value: $F V n=P V \times(1+r) n$ Present value: $\quad P V=C F /(1+r)-n$ Net present value: $\mathrm{NPV}=$ $\mathrm{PV}-\mathrm{P} 0$ 


\section{International Journal of Business Management and Economic Review}

Vol. 3, No. 02; 2020

ISSN: 2581-4664

In which: FV (Future Value) stands for future value of the project; PV (Present Value) stands for the present value of the amount incurred in the future; CF (Cash Flow Future) stands for the amount of money at the end point of the future period $n$; $r$ stands for the discount rate or the current rate; $\mathrm{n}$ stands for the number of discount periods; NPV (Net Present Value) stands for the net present value or net income calculated to the present time. the net income is reflected by those of criterias and calculated for a unit of investment capital; P0 is the initial present value.

Project evaluation: If projects are not mutually exclusive, choose projects with NPV>0; If the projects mutually exclusive, select projects with NPV max: If there are some constraints on invested capital, choose projects with NPV max.

Benefit / cost rate: $\mathrm{BCR}=$ total present value benefit / total cost of current value. The projects with $\mathrm{BCR}>1$ and $\mathrm{BCR}$ max are usually selected; With regard to independent projects: select projects with $\mathrm{BCR}>1$; In terms of mutually exclusive projects, it is the combination of both BCR and NPV

Internal Rate of Return (IRR). The higher the IRR, the more effective the project is; If IRR = const, the smaller $r$ is, the more effective the project is; If $r=$ const, the larger the IRR, the more effective the project is; In terms of independent projects: NPV>0, this project will be chosen; Regarding the projects are mutually exclusive: IRR and NPV will be co-operated.

Step 6: Analyze the distribution. Compare and rank options. Step 7: Sensitivity analysis.

Step 8: Give the proposals.

Step 9: Final report..

To analyze the effectiveness of the benefits and costs of the SLS project on NH1, from the junctions, bridges, pagodas, to Tan Hiep town centre, Chau Thanh district, Tien Giang province, the author team carry on from step 1 to step 5 of CBA method.

\section{Actual situation of the lighting system on NH1 through Chau Thanh - Tien Giang'}

Tien Giang province has NH1, NH50 and NH60 which are managed by the Government with dense traffic density. In NH1 only, there are 150,000 vehicles per day, including over 50,000 cars, most of them are car, truck and container.

In fact, in previous years, taking advantage of the dark sky, some unkind people in the adjacent areas to Long An province run along NH1 to rob the property from the passengers such as: gold, motorbikes, mobile phones, etc. Some people also used weapons to stop cars, seize and destroy property. To handle this issue, the Traffic Safety Committee coordinated with the Department of Transport of Tien Giang province to conduct a survey of the area, advise the People's Committee to install SLS, sign boards,improve the facilities both sides of $\mathrm{NH} 1$, in which the investment for the system is over 25 billion VND from the local budget. In addition, to increase the effective promotion the light at night, the Traffic Safety Committee cooperates with the Traffic Police, the Traffic Inspectorate and the Road Administration IV.3. dismantling signs, advertising panels, trimming trees obscuring visibility on NH1 through Tien Giang province - over $70 \mathrm{~km}$. 


\section{International Journal of Business Management and Economic Review}

Vol. 3, No. 02; 2020

ISSN: 2581-4664

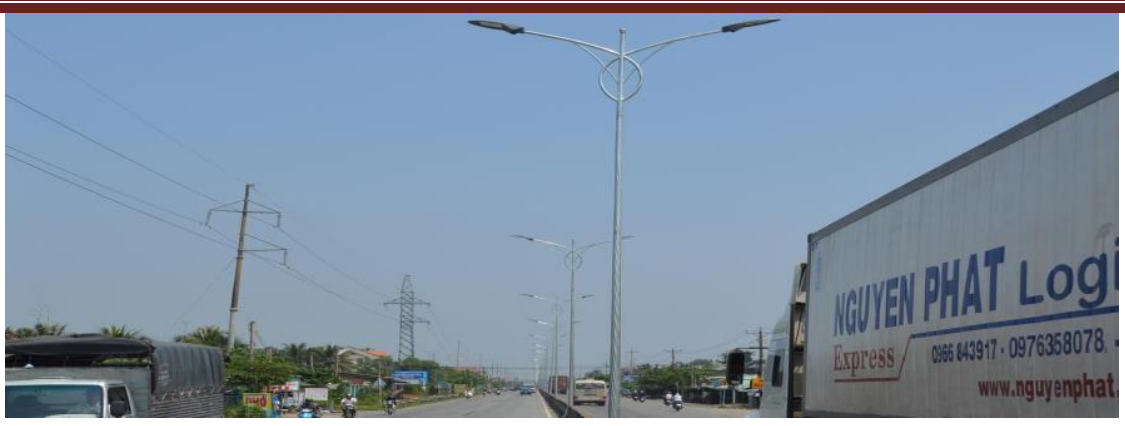

Fig. 1. Lighting systems on NH1

As a gateway to the West, there are many important transportation routes, effectively serving the travel and freight of people in the Mekong River region. The problem of traffic accidents on the roads in Tien Giang is extremely alarming. According to recent statistics, only after Ho Chi Minh City, Hanoi, Dong Nai and Binh Duong, Tien Giang account for fifth ranking. across the country on the number of deaths due to traffic accidents.

Through actual results on NH1, some locations where the median strip was opened,from the junctions, bridges, pagodas, to Tan Hiep town centre, Chau Thanh district, Tien Giang province where SLS has not been installed. At these points, traffic is very complicated causing accidents due to very high vehicle speeds. As the results, the investment in building public SLS is to ensures the necessary light for vehicles in traffic at these locations, The construction will contribute to reducing traffic accidents in the area, ensure security the Southern region.

General view about SLS on NH1 at the opening median strip,from the junctions, bridges, pagodas, to Tan Hiep town centre, Chau Thanh district, Tien Giang province

+ Level of works (project): works of technical infrastructure works, level: III, IV.

+ The average life-cycle of the project is 10 years

+ Scale: 03 categories

* Category 01:SLS at the junctions on NH1 in Chau Thanh district (Km 1961+400, Km 1974+700, Km1979+000, Km 1980+600, Km 1982+300):

- $\quad$ At the open median strip on NH1 Km 1961+400:

$>$ Newly installed 02 lighting control cabinets.

Newly installed 03 SLS box: $8 \mathrm{~m}$ high pillar, the need of $2 \mathrm{~m}$ high and $1.5 \mathrm{~m}$ in horizontal with $150 \mathrm{~W}$ induction light.

- $\quad$ At the open median strip on NH1 Km 1974+700:

$>$ Newly installed 01 lighting control cabinets.

$>$ Newly installed 01 SLS box:8m high pillar, the need of $2 \mathrm{~m}$ high and $1.5 \mathrm{~m}$ in horizontal, induction light with $150 \mathrm{~W}$.

Newly installed 01 SLS box: $6 \mathrm{~m}$ high pillar, the need of $2 \mathrm{~m}$ high and $1.5 \mathrm{~m}$ in horizontal with $150 \mathrm{~W}$ induction light.

- $\quad$ At the open median strip on NH1 Km 1979+000:

$>$ Newly installed 02 lighting control cabinets. 


\section{International Journal of Business Management and Economic Review}

Vol. 3, No. 02; 2020

ISSN: 2581-4664

$>$ Newly installed 01 SLS box: $8 \mathrm{~m}$ high pillar, the need of $2 \mathrm{~m}$ high and $1.5 \mathrm{~m}$ in horizontal with $150 \mathrm{~W}$ induction light.

$>\quad$ Newly installed 01 SLS box: $6 \mathrm{~m}$ high pillar, the need of $2 \mathrm{~m}$ high and $1.5 \mathrm{~m}$ in horizontal with $150 \mathrm{~W}$ induction light.

- $\quad$ At the open median strip on NH1 Km 1980+600:

$>$ Newly installed 01 lighting control cabinets.

$>$ Newly installed 01 SLS box: $8 \mathrm{~m}$ high pillar, the need of $2 \mathrm{~m}$ high and $1.5 \mathrm{~m}$ in horizontal with $150 \mathrm{~W}$ induction light.

$>$ Newly installed 02 SLS box: $6 \mathrm{~m}$ high pillar, the need of $2 \mathrm{~m}$ high and $1.5 \mathrm{~m}$ in horizontal with $150 \mathrm{~W}$ induction light.

- $\quad$ At the open median strip on NH1 Km 1982+300:

$>$ Newly installed 02 lighting control cabinets.

$>$ Newly installed 01 SLS box: $8 \mathrm{~m}$ high pillar, the need of $2 \mathrm{~m}$ high and $1.5 \mathrm{~m}$ in horizontal with $150 \mathrm{~W}$ induction light.

$>$ Newly installed 02 SLS box: $6 \mathrm{~m}$ high pillar, the need of $2 \mathrm{~m}$ high and $1.5 \mathrm{~m}$ in horizontal with $150 \mathrm{~W}$ induction light.

*Category 02: SLS from Ben Chua Bridge đến Lương Phú Intersection (Km1963+600 đến Km 1966+600):

$>$ Install 4 new PLC control cabinets with 50A capacity. The power supply for the control cabinets is taken from the current low voltage pylons on the NH1.

$>$ Install 78 new spiral tapered cylinders 8 meters high and a pair bar of 2 meters in high and 1.5 meters in horizontal.

$>\quad$ Install $156143 \mathrm{~W}$ power-saving bulbs.

$>$ Newly installed 3358 meters of $3 * 16 \mathrm{~mm}$ low voltage underground cables which is in HDPE D65/50 bearing twisted pipe. If it passes through NH1, this road will be drilled in order that cables will be stored in the D60 galvanized iron pipe.

*Category 03: SLS from Luong Phu intersection to Tan Hiep Town (Km1960+700 đến Km1963+600):

>Install 4 new PLC control cabinets with 50A capacity. The power supply for the control cabinets is taken from the current low voltage pylons on the NH1.

$>$ Install 72 new spiral tapered cylinders 8 meters high and a pair bar of 2 meters in high and 1.5 meters in horizontal.

$>$ Install $144143 \mathrm{~W}$ power-saving bulbs.

$>$ Newly installed 3424 meters of $3 * 16 \mathrm{~mm}$ low voltage underground cables which is in HDPE D65/50 bearing twisted pipe. If it passes through $\mathrm{NH} 1$, this road will be drilled in order that cables will be stored in the D60 galvanized iron pipe.

Analysis of benefits and investment costs of installing lighting systems on NH1 at the locations of the opening of median strips, intersections from Ben Chua bridge to Tan Hiep town in Chau Thanh district, Tien Giang province.

\section{Analisis scale}

The SLS project on National Highway 1 at the locations of the opening of the median strip, the intersections from Ben Chua bridge to Tan Hiep town in Chau Thanh district, Tien Giang province is invested by the government's budget which ensure the necessary lighting conditions 


\section{International Journal of Business Management and Economic Review}

Vol. 3, No. 02; 2020

ISSN: 2581-4664

to adapt with 150,000 vehicles every day and night through $\mathrm{NH}$, including over 50,000 cars, trucks and container trucks. Therefore, the economic cost of the project is quantified by the project expenditures throughout the project life cycle, from which economic costs include project investment costs, maintenance costs, and project operation costs. Economic costs are calculated based on the converted financial costs at current prices and the conversion ratio between financial prices and economic prices

The economic benefit of the project in the context of this study is to collect data to estimate the socio-economic benefits from people living along both $\mathrm{NH} 1$ and the users of the vehicles on the road which is known as the travel saving cost for the resident (within the possible quantifiable scale) in the case of a current project compared to before the project.

\section{The analysis criterias Currency and inflation}

VND is the main currency used in this research. During inflation time period, market prices and costs do not measure the true value of cost benefits. The value of benefits and costs increases even though their real values may not increase. Therefore, when analyzing the project cash flow, the benefits and costs of the project needs to be adjusted according to the change of inflation rate during the project implementation period. According to World Bank statistics and IMF about Vietnam's average inflation rate, the project uses the average annual inflation rate for VND to assume $7 \%$ from 2018 to 2028.

The time

Indeed, if the project were started construction in mid-2018, the project analysis period would have started in 2018 and 2018 was the year 0 of the project, the project was expected to be completed within 3 months.

The project analysis period is 10 years (due to the technical standards of the design and construction level of the project should have a 10-year lifespan), from 2018 to 2028, afterward, the project will continue to be used.

The investment of installing SLS project

State's budget capital is estimated by the table below:

\begin{tabular}{|c|l|r|}
\hline & \multicolumn{1}{|c|}{ CATEGORY COST } & \multicolumn{1}{|c|}{ AMOUNT (VND) } \\
\hline 1 & CONSTRUCTION COSTS & $\mathbf{1 0 . 2 6 5 . 3 4 0 . 9 5 6}$ \\
\hline 2 & PROJECT MANAGEMENT COSTS & 757.846 .700 \\
\hline 3 & $\begin{array}{l}\text { COST OONSTRUCTION } \\
\text { INVESTMENT CONSULTANCY }\end{array}$ & 745.667 .375 \\
\hline 4 & OTHER COST & 601.913 .337 \\
\hline 5 & REDUNDANCY COSTS & $\mathbf{1 2 . 6 4 0 . 1 8 0 . 0 8 2}$ \\
\hline & TOTALIY
\end{tabular}

Source: Branch of EPSAN Technical Joint Stock Company and Hoang Viet Investment Consulting Joint Stock Company

From which:

Construction expenses include: direct expenses, general expenses, pre-calculated taxable income and value-added tax. Construction expenses are calculated by the bill of quantity and applying the imposing unit price of materials, labor and machines.

Management cost: $2,763 \%$ of pre-tax cost. 


\section{International Journal of Business Management and Economic Review}

Vol. 3, No. 02; 2020

ISSN: 2581-4664

Construction consultant expenses include: expenses technical-economic reports; expenses for verification of technical-economic reports; expenses for bidding documents, bid evaluation; expenses for evaluation of construction bidding documents; fees for review of bidding results; expenses for handling contractor's petitions; construction supervision costs.

Other costs include: Costs of general items; settlement verification and approval expenses; independent audit costs; insurance costs.

Contingency cost: $5 \%$ of construction cost, project management cost, construction consultancy cost and other expenses.

\section{Implementation schedule}

Due to the urgent use requirements above as well as ensuring that the project is soon completed and put into use, the project implementation schedule is expected by the table below:

\begin{tabular}{|c|l|c|c|c|}
\hline \multirow{2}{*}{ ACTIVITY } & \multicolumn{3}{c|}{ MONTH } \\
\cline { 3 - 6 } & & $\mathbf{0 1}$ & $\mathbf{0 2}$ & $\mathbf{0 3}$ \\
\hline 1 & Examination & & & \\
\hline 2 & Engineering documents & & & \\
\hline 3 & Evaluation of engineering documents & & & \\
\hline 4 & Bidding documents & & & \\
\hline 5 & Construction bidding & & & \\
\hline 6 & Construction & & & \\
\hline 7 & Project inspection, implementation & & & - \\
\hline 8 & Summary & & & \\
\hline
\end{tabular}

Fig. 2. Installation of lighting systems on NH1 isto reduce traffic accidents

The economic criterias Cost of capital

$\mathrm{WACC}=+(1-\mathrm{t})$

WACC $=0,85 * 9 \%+0,15 * 11 \% *(1-20 \%)=9 \%$

In which: WACC is weight average cost of capital; Ke is owner's equity cost $=9 \%$; $\mathrm{Kd}$ is interest rate $=11 \%$; $\mathrm{E}$ is equity value; $\mathrm{D}$ loan value / investment capital; $\mathrm{t}$ is the corporate income tax.

As the results, the Cost of Debt after Tax the project is $9 \%$, besides that, during inflation, market prices and costs do not measure the true value of cost benefits. The value of benefits and costs increases even though their real values do not increase. That perhaps draw for a special consideration that when analyzing the project cash flow, the benefits and costs of the project needs to be adjusted according to the change of inflation rate during the project implementation period. In terms of the impact of inflation, if inflation increases the cost of debt after tax after $1 \%$, the cost of debt after tax of project would growth $10 \%$.

Financial revenue

Regarding society merits, which is primarily the benefit of the road user through NH1 of all social classes, the citizen across along to this project, enterprises take advantages revenue from consultancy, design, construction, operation, project maintenance, project implementation, project management, implementation, and management experience of the investor demand for local socio-economic development. Therefore, the project's revenue source:

Table 1.Summary of project revenues from a society perspectives (research team analysis) 


\section{International Journal of Business Management and Economic Review}

Vol. 3, No. 02; 2020

ISSN: 2581-4664

PROJECT REVERNUE RESOURCES IN SOCIAL VIEWPOINTS (VND)

\begin{tabular}{|c|c|c|r|r|l|}
\hline Year & $\begin{array}{c}\text { Budget for } \\
\text { project }\end{array}$ & $\begin{array}{c}\text { Electricity } \\
\text { supply revenue }\end{array}$ & $\begin{array}{c}\text { Externalities } \\
\text { (saving time, } \\
\text { human being; } \\
\text { the system } \\
\text { maintenance } \\
\text { production } \\
\text { and business } \\
\text { bases along } \\
\text { both sides of } \\
\text { NH1) }\end{array}$ & Totall amount \\
\hline 1 & 12.640 .180 .082 & 100.554 .261 & 0 & 4.583 .280 .000 & 17.324 .014 .343 \\
\hline 2 & 0 & 101.559 .804 & 25.663 .352 & 4.583 .280 .000 & 4.710 .503 .156 \\
\hline 3 & 0 & 102.575 .402 & 25.919 .986 & 4.629 .112 .800 & 4.757 .608 .187 \\
\hline 4 & 0 & 103.601 .156 & 26.179 .185 & 4.675 .403 .928 & 4.805 .184 .269 \\
\hline 5 & 0 & 104.637 .167 & 26.440 .977 & 4.722 .157 .967 & 4.853 .236 .112 \\
\hline 6 & 0 & 105.683 .539 & 26.705 .387 & 4.769 .379 .547 & 4.901 .768 .473 \\
\hline 7 & 0 & 106.740 .374 & 26.972 .441 & 4.817 .073 .342 & 4.950 .786 .158 \\
\hline 8 & 0 & 107.807 .778 & 27.242 .165 & 4.865 .244 .076 & 5.000 .294 .019 \\
\hline 9 & 0 & 108.885 .856 & 27.514 .587 & 4.913 .896 .517 & 5.050 .296 .959 \\
\hline 10 & 0 & 109.974 .714 & 27.789 .733 & 4.963 .035 .482 & 5.100 .799 .929 \\
\hline
\end{tabular}

Economic benefits of the project

Firstly, reducing the travel time of people at night (from 18:30 to 22:00) to ensures enough ideal visibility of SLS for people in traffic. According to the Circular No. 58/2009 / TT-BCA (C11) dated October 28, 2009 providing guidance on statistics, summarizing and building databases, providing information on road clearly identify traffic accidents, traffic accidents, including four classifications of traffic accidents causing less serious consequences, traffic accidents causing serious consequences, traffic accidents causing very serious consequences, traffic accidents causing extremely serious consequences.on average, to solve one traffic accidents (excluding traffic collisions), the functional forces need to take steps according to the prescribed procedures on the basis of verifying the necessary information to be collected, handle and adjust. traffic, disperse the crowd for vehicles to continue moving smoothly. Moreover, statistics of traffic accidents in the installation road of SLS in recent years, from less serious to extremely serious, have caused local congestion for hours due to vehicles across the road. It usually takes a long time, an average of 1 traffic accident case takes at least 30 minutes to handle the status and get the initial deposition. If there were 8 traffic accidents a year on average, it takes 4 hours to process. In fact, according to the statistics of the authorities in QL1 only, there are 150,000 traffic times a day and night, from which there are over 50,000 cars, most of them including passenger cars, trucks and container trucks. Relative convention is 01 means of representing 01 employee. The number of travel time for everyone will be saved by the following caculation, (assuming no congestion due to traffic accidents) that are guaranteed by SLS is $150,000 \times 4=$ 600,000 hours / year.

This route passes Tan Huong and Long Giang Industrial Zone, in which, the number of workers is up to tens of thousands.

The income of employees currently reaches over 5.5 million VND / month on average according a survey on the situation of labor, wages, income, spending, life of employees in enterprises in 2018 by the Vietnam General Confederation of Labor.

On average, for 1 hour, the income of a normal laborer is: VND 5,500,000 / 30 days / 24 hours $=\mathrm{VND} 7,638.8 \mathrm{VND} /$ hour. 


\section{International Journal of Business Management and Economic Review}

Vol. 3, No. 02; 2020

ISSN: 2581-4664

This shows the opportunity cost for the society (assuming no congestion due to traffic accidents on the research road section) is: 600,000 hours $\mathrm{x} 7,638.8 \mathrm{VND} /$ hour $=4,583,280,000$ VND / year.

Secondly, benefits of the electricity supplier:

Duration of consumption is from 18:30 hrs to $22: 00 \mathrm{hrs}$ ( $3.5 \mathrm{hrs);} \mathrm{220V} \mathrm{-} 1$ phase. Capacity:

* Category: SLS at the intersections on NH1 in Chau Thanh district (Km 1961+400, Km 1974+700, Km1979+000, Km 1980+600, Km 1982+300): 150W high frequency

induction lamp $=0,15 \mathrm{~kW}$.

Formula to calculate power consumption: $\mathrm{A}=\mathrm{P} . \mathrm{t}$

In which: $\mathrm{A}$ is the number of electric consumption of the equipment $(\mathrm{kWh}) ; \mathrm{P}$ is potestas or capacity on the electric equipment $(\mathrm{W})$; $\mathrm{t}$ is the figure for the time using electricity $(\mathrm{h})$

$\Rightarrow$ The capacity of 1 bulb per day: $0,15 \times 3,5=0,525 \mathrm{kWh}$. There are 13 single bulbs in this SLS category.

The capacity for 1 year : 0,525 x $365=191,625 \mathrm{kWh}$ According the electricity price list of Vietnam Electricity:

The unit receiving and using fixed assets (FA) - works is the Department of Economic and Infrastructure of Chau Thanh district, which has to pay to Electricity every year: 191,625 kWh x $1,755 \mathrm{VND} / \mathrm{kWh} \times 13$ poles $=4,371,924.4 \mathrm{VND}$.

However, according to the regulations of the first 72 hours after handing over the project, the electricity paid by the contractor: 4,371,924.4 VND - $(0.15 \times 72 \times 1,755)=4,352,970.4$ VND.

* Category: SLS on NH1 from Ben Chua Bridge to Luong Phu intersection (Km1963+600 đến Km 1966+600) and Category: SLS on NH1 from Luong Phu intersection to Tan Hiep Town (Km1960+700 đến Km1963+600): 143W LED = 0,143 Kw (double bulbs)

$\Rightarrow>$ The capacity of 1 bulb per day: $0.143 \times 3.5=0.5005 \mathrm{kWh}$. There are 150 bulbs in those two categories.

The capacity for 1 year: $0,5005 \times 365=182,6825 \mathrm{kWh}$. According the electricity price list of Vietnam Electricity:

The unit receiving and using fixed assets (FA) - works is the Department of Economic and Infrastructure of Chau Thanh district, which has to pay to Electricity every year: $182,6825 \mathrm{kWh}$ x 1,755 VND/kWh x $(156+144)$ trụ $=96,182,337$ dồng.

However, according to the regulations of the first 72 hours after handing over the project, the electricity paid by the contractor:: 96,182,337 đồng $-(0.143 \times 72 \times 1,755)=96,164,268$ đồng. In short, the total payment: 4,352,970.4 VND + 96,164,268 VND=100,517,238 VND.

Economic analysis results are presented in Table 2 below:.

Table 2.Table of benefits data when operating project (analysis research ) Economic cost of the project 


\section{International Journal of Business Management and Economic Review}

Vol. 3, No. 02; 2020

ISSN: 2581-4664

\begin{tabular}{|l|c|c|}
\hline \multicolumn{1}{|c|}{ Category } & Unit & Value \\
\hline l. The primary benefit parameters & & \\
\hline $\begin{array}{l}\text { Saving time, costs, and money due to traffic congestion in the } \\
\text { case of non-guarantee SLS }\end{array}$ & (VND/year) & 4.583 .280 .000 \\
\hline $\begin{array}{l}\text { Profit of EVN by providing power and operating the system of } \\
\text { the project (based on the announcement of EVN's business } \\
\text { results in the first 6 months) }\end{array}$ & $11,5 \%$ \\
\hline 2. Economic benefits throughout each year & CND/year) & \\
\hline The year 2018 & & \\
\hline The year 2019 & & 3.828 .510 .749 \\
\hline The year 2020 & & 1.666 .623 .980 \\
\hline The year 2021 & 1.703 .290 .220 \\
\hline The year 2022 & 1.740 .323 .112 \\
\hline The year 2023 & & 1.777 .726 .354 \\
\hline The year 2024 & & 1.815 .503 .617 \\
\hline The year 2025 & & 1.853 .658 .653 \\
\hline The year 2026 & & 1.892 .195 .240 \\
\hline The year 2027 & & 1.931 .117 .192 \\
\hline The year2028 & & 1.970 .428 .364 \\
\hline
\end{tabular}

Instead of construction investment, it is also included the costs of operating and maintaining the SLS system.

The disbursement progress assumes the first year due to the capital, which is considered as a cash flow, high revenues and costs in the first year. On the other hand, because the project completed in 3 months from the budget, we consider this cash into the cash inflow. After that, the new project was handed over and put into use by another unit (not the investor). in terms of view of social benefit in the second year, the cash flow in and out involve the remaining relevant factors: electricity consumption, maintenance, quantification of time saving should be divided equally for latter years (including inflation).

Assuming the cost of labor accounts for $5 \%$ of construction costs, of which all are skilled labor. The labor conversion coefficient for skilled workers due to their easy access to work, therefore, it is assumed that the coefficient is 1 .

Conversion ratio of raw materials, machinery and equipment: According Circular No. 131/2008 / TT-BTC, the tax rate for major raw materials, machinery and equipment is $10 \%$, therefore, the research team suppose that the conversion coefficient between economic and financial costs of construction costs and equipment costs equals by 0.9

Other cost items: consulting costs, other expenses, provision costs assume that the economic price is equal to the financial price, ie the conversion coefficient equals 1.

Operating cost: after the project is completed, the estimated operating cost of electricity consumed for SLS is over VND 100 million / year. Because Electricity employees work in management and engineering fields mostly incharge, the conversion ratio between financial and economic prices is 1 .

Annual expenses for maintenance of construction include: expenses for maintenance planning, estimation of maintenance, evaluation, verification and other relevant expenses; expenses for regular and periodic work inspection; cost of project maintenance according to annual maintenance plan; Expenses for making and managing construction work maintenance dossiers are determined by the percentage norm $(\%)$ compared with the construction expenses and the cost of construction equipment (excluding the technological equipment part of (works) calculated according to the investment capital rate of works of the same type and the same level at the time of planning maintenance. 


\section{International Journal of Business Management and Economic Review}

Vol. 3, No. 02; 2020

ISSN: 2581-4664

The cost of maintenance of construction works includes two types of costs: materials, equipment and labor: labor costs account for $20 \%$ of maintenance costs (in assume), while the remaining $80 \%$ is costs of construction materials. . In which, the conversion coefficient of construction materials and equipment as above is 0.9 , the assumed labor costs are all people with working skills, the coefficient is 1 .

Table 3. The conversion factor CF (analysis research ) Depreciation

\begin{tabular}{|l|r|r|c|}
\hline \multicolumn{1}{|c|}{ Category } & $\begin{array}{c}\text { Financial price } \\
\text { (VND) }\end{array}$ & $\begin{array}{c}\text { Economic Price } \\
\text { (VND) }\end{array}$ & $\begin{array}{c}\text { CF } \\
\text { coefficient }\end{array}$ \\
\hline 1.Initial investment including: & & $\mathbf{1 2 . 6 4 0 . 1 8 0 . 0 8 2}$ & \\
\hline - Construction costs & 10.265 .340 .957 & 9.238 .806 .861 & 0,9 \\
\hline - Project management cost & 206.277 .360 & 206.277 .360 & 1 \\
\hline - Consulting cost & 769.411 .714 & 769.411 .714 & 1 \\
\hline - Other costs & 745.667 .375 & 745.667 .375 & 1 \\
\hline - Redundancy costs & 601.913 .337 & 601.913 .337 & 1 \\
\hline 2. Maintaining and operating costs & 1.299 .196 .097 & $\mathbf{1 . 2 7 8 . 6 6 5 . 4 1 1}$ & \\
\hline Maintaining cost & 1.042 .562 .573 & 1.042 .562 .573 & 1 \\
\hline Operating cost including & 256.633 .524 & 236.102 .838 & \\
\hline - Construction and equipment costs & 205.306 .820 & 184.776 .138 & 0,9 \\
\hline - Labour costs & 51.326 .700 & 51.326 .700 & 1 \\
\hline
\end{tabular}

All investment costs are included in the straight-line depreciation method, which is assumed to be 10 years (from 2019 to 2028) for all categories.

\section{Corporate income tax}

The enterprise income tax is a direct tax, directly levied on the income of a taxpayer as stated above. The corporate income tax rate in Article 11 of Circular 78/2014 / TT- BTC is 20\%, this research assume the whole project need to pay this tax rate.

\section{Results of economic analysis}

Use discount factors to calculate the price of a future value. The net present cash flow value with $10 \%$ cost of capital, the analysis results are shown as below:

Table 4. benefits and annual costs flow (analysis research)

\begin{tabular}{|c|c|c|c|c|c|}
\hline \multirow{2}{*}{\multicolumn{2}{|c|}{ The year }} & \multirow{3}{*}{$\begin{array}{c}\begin{array}{c}\text { General } \\
\text { Benefit }\end{array} \\
\text { Saving for the } \\
\text { road user } \\
\text { (VND) }\end{array}$} & \multicolumn{2}{|c|}{ Economic Expense } & \multirow{3}{*}{$\begin{array}{c}\text { The net present } \\
\text { value of cash } \\
\text { flows, the } \\
\text { capital expense } \\
\text { 10\% } \\
\text { (VND) } \\
25.147 .621 .234 .97\end{array}$} \\
\hline & & & \multirow{2}{*}{$\begin{array}{c}\text { Investment } \\
\text { Expense } \\
\text { (VND) }\end{array}$} & \multirow{2}{*}{$\begin{array}{l}\text { Operating, } \\
\text { maintaining, } \\
\text { repairing } \\
\text { costs expense } \\
\text { (VND) }\end{array}$} & \\
\hline $\mathrm{O}$ & 2018 & & & & \\
\hline 1 & 2019 & $3.828 .510 .749,60$ & 9.937 .858 .669 & 100.517 .237 & $5.600 .451 .990,80$ \\
\hline 2 & 2020 & 1.666 .623 .980 .80 & $\mathrm{O}$ & 126.217 .613 & $3.263 .077 .751,43$ \\
\hline 3 & 2021 & $1.703 .290 .220,61$ & 0 & 127.479 .790 & $2.913 .090 .969,49$ \\
\hline 4 & 2022 & 1.740 .323 .122 .81 & 0 & 128.754 .587 & $2.600 .669 .582,63$ \\
\hline 5 & 2023 & $1.777 .726 .354,04$ & 0 & 130.042 .133 & $2.321 .778 .482,14$ \\
\hline 6 & 2024 & $1.815 .503 .617,58$ & 0 & 131.342 .554 & 2.072 .816 .342 .73 \\
\hline 7 & 2025 & 1.853 .658 .653 .76 & 0 & 132.655 .980 & $1.850 .568 .950,02$ \\
\hline 8 & 2026 & $1.892 .195 .240,30$ & 0 & 133.982 .479 & $1.652 .167 .554,25$ \\
\hline 9 & 2027 & $1.931 .117 .192,70$ & o & 135.322 .365 & $1.475 .051 .708,39$ \\
\hline 10 & 2028 & 1.970 .428 .364 .63 & 0 & 136.675 .589 & $1.397 .947 .903,09$ \\
\hline
\end{tabular}

According to the calculation results of the research team, the net present value of the project 


\section{International Journal of Business Management and Economic Review}

Vol. 3, No. 02; 2020

ISSN: 2581-4664

$\mathrm{NPV}=\mathrm{VND} 3,334,896,268.29$ when the discount rate is $10 \%$, so the internal rate of return IRR must exceed $10 \%$. When the internal rate of return is about $13 \%$, the net present value is witnessed 147,621,234.97 VND. when the internal rate of return is $14 \%$ in use, the net present value is witnessed $784,815,685,81$. Therefore, the internal rate of return is near $13.5 \%$, IRR $=$ $13.16 \%$.

As a result,, in terms of numerical results, we have NPV $=3,334,896,268.29$ when the discount rate is $10 \%$; $\mathrm{BCR}=1.64$ when the discount rate is $10 \%$; IRR $=$ at approximately $13.5 \%$ $(13.16 \%)$.

The net present value is positive when the social discount rate by $10 \%$ so that under this criterion the project will be selected. The benefit-cost ratio is greater than 1.0 at the social discount rate, so the project will also be approved under this criterion. The internal rate of return is greater than the social discount rate so the project will be approved. To put it in the nutshell, all three criteria indicate that the project is economically feasible.

\section{Project risk analysis}

It is well known that the project appraisal is based on project-life forecast data, however, these data may change and affect the results and effectiveness of the project. Therefore, risk analysis will help to know the extent of the impact of the parameters that affect more or less on the effectiveness of the project, with regard to special considerations and foreseeing negative impacts on the project, owner, proactively take action corrective measures when implementing the project.

From the results of economic analysis, it is well seen from the NPV of the project is greater than zero, so the sensitivity analysis will be in a negative direction to consider the possibility of variables affecting the economic efficiency of the project.

Increase the operating time of the SLS: The operation time of the SLS depends on the lifespan and capacity of the lights and underground power cables system. Because the analysis has calculated NPV is greater than zero, we assume the accommodation capacity decreases by $0.5 ; 1$ hour; 1.5 hours (the lighting time estimate: 3.5 hours from 18:30 to 22:00), the results are as below:

Table 5.The results of the sensitivity analysis increase the lighting time (calculated by the research team)

\begin{tabular}{|c|c|c|c|c|}
\hline \multirow{2}{*}{ Index } & Basic & \multicolumn{3}{|c|}{$\begin{array}{c}\text { The number of increasing lighting time in } \\
\text { comparison with the forecast }\end{array}$} \\
\cline { 2 - 5 } & $\begin{array}{c}\mathbf{3 , 5} \text { hours } \\
(\mathbf{0} \%)\end{array}$ & $\begin{array}{c}\mathbf{4} \text { hours } \\
(+\mathbf{1 4} \%)\end{array}$ & $\begin{array}{c}\mathbf{4 , 5} \text { hours } \\
(+\mathbf{2 8}, \mathbf{5} \%)\end{array}$ & $\begin{array}{c}\mathbf{5} \text { hours } \\
\mathbf{( + 4 3 \% )}\end{array}$ \\
\hline $\begin{array}{c}\text { NPV } \\
\text { Economy }\end{array}$ & $3.334 .896 .268,29$ & $3.262 .183 .479,50$ & $3.189 .497 .617,26$ & $3.091 .471 .775,98$ \\
\hline
\end{tabular}

The operation time of the SLS system has a very strong impact on the project results, and it can be said that the risk is very high and the time is proportional to the power consumption of each lamp in the system. The analysis results show that, only increase the lighting time to the limit at night to increase lighting to 5 hours compared to the forecast, whilst the NPV of the project is 


\section{International Journal of Business Management and Economic Review}

Vol. 3, No. 02; 2020

ISSN: 2581-4664

still positive. Therefore, the factor of power consumption does not significantly affect the cost benefits of the total project.

\section{Increase investment costs:}

Baseline analysis model, the investment cost was calculated from 2017, but the increase in raw material prices and other costs also depends on the price of supply and demand of goods in the market. Therefore, we assume that the cost of economic investment fluctuates by $5 \%, 10 \%$, and $15 \%$.

Table 6.The results of sensitivity analysis of the rate of increase of investment capital (research team)

\begin{tabular}{|c|c|c|c|c|}
\hline \multirow{2}{*}{ Index } & Basic & \multicolumn{3}{|c|}{ Increasing capital } \\
\cline { 2 - 5 } & $\mathbf{0 \%}$ & $\mathbf{5 \%}$ & $\mathbf{1 0 \%}$ & $\mathbf{1 5 \%}$ \\
\hline $\begin{array}{c}\text { NPV } \\
\text { Economy }\end{array}$ & $3.334 .896 .268,29$ & $1.939 .497 .617,26$ & $689.497 .617,26$ & $-560.502 .382,74$ \\
\hline
\end{tabular}

According the analysis of some factors affecting the project shows that the NPV of project is quite sensitive to bad situations, but this is a project for social security purposes which is one of the important political tasks of the Government. Department of Transport should implement construction to ensure the schedule, good management, use for the right purpose, preserve, maintain and maintain regular works of the SLS system in long term for the daily life ofthe road user and the resident along to NH1 in Tien Giang province.'

\section{The benefits were not quantified within the study}

*Save time, costs, reduce environmental pollution: If the SLS were not installed, the traffic condition would have not adapted with the road user's, the resident's requirement and it would have took a long time to be stuck in the traffic congestion from an accident not mentioned the fact that the emission from the vehicles have would exhausted into the environment in peak hours

*Impact on traffic safety: When the project is put into use, it will shorten the travel time of the vehicle by providing sufficient light to ensure necessary conditions of traffic, which means reducing the possibility of uncertainty due to traffic accident. Reducing traffic accidents means the benefits of reducing the costs of wounded and deaths even important material damages. However, due to time constraints, this content has not been quantified yet.

*Impact on the spiritual life of people: When the project is in use, it will bring great indirect benefits such as people committing convenient transportation at night, the volume of agricultural and other goods (tons.km) will be transported in a more safety road. Especially, the SLS system has the key role for the thousands labour working in Tan Huong and Long Giang Industrial zone when they finish night shift.

*Increasing urban view and brand value of the region of Tien Giang province: The project will increase the regional brand value of Tien Giang province in the inter- regional and interregional connection process. The SLS system contributes to ensure traffic safety, social security and order, the view of the urban landscape, promote trade and tourism activities and indirectly contribute to increasing the quantity of kife condition for the citizen. When the SLS system is 


\section{International Journal of Business Management and Economic Review}

Vol. 3, No. 02; 2020

ISSN: 2581-4664

seriously invested and built, it is a sign to form concentrated residential areas and pave the way for the development of new urban areas..

*Impacts on economic growth and investment attraction: During the implementation of the project, the consumption of construction materials will increase to create more jobs for workers. The completion of the project will contribute to perfecting the transportation infrastructure of NH1 route, service activities along both sides of the route and surrounding areas, developing more surrounding, devoteing income to the general economy.

Management implication in improving the efficiency of lighting system investment on NH1 at the opening median strip,from the junctions, bridges, pagodas, to Tan Hiep town centre, Chau Thanh district, Tien Giang province

\section{Mechanisms and policies to attract investment capital}

In order to increase investment sources for the development of transport systems in Chau Thanh district, especially for SLS, traffic on NH1 needs to have specific mechanisms and policies to attract investment capital such as: mobilizing capital from contributions from borrowed capital sources (government preferential credit loans, bank credits, etc.), from entrepreneurs, finance organizations, individuals, etc. in the district. Participate in forms of stocks and government bonds to invest in developing economic infrastructure, specifically in transport infrastructure.

\section{Manage the capital effectively}

The investment decisions of transport lighting works in the district area must be based on the development planning of transportation system approved by the Government, People's Committees

In bidding: equality regardless of ownership type, the price floor needs to be applied, preventing low bidding affecting the quality and progress of works. Strengthening the work quality inspection and management; Implementing a public audit of enterprise capacity and project investment; Promoting the supervision role of the population community is primarily for traffic lighting works.

\section{CONCLUSION}

The NH1 section running through Tien Giang province play an profound impact on traffic of the Southwest region. From HCMC to Can Tho, Dong Thap, Kien Giang, An Giang, Ca Mau, etc.or the opposite route, most of people have to cross this road. At the same time, this is also a critical road for promoting the exchange and economic development support between the two industrial regions and almost provinces in the South of Vietnam together.

The study analyzed the feasibility of the SLS project on NH1, at the intersections and from Ben Chua Bridge to Tan Hiep Town in Chau Thanh District, Tien Giang, it is necessary to ensure the street light system for the citizen, save vast of time and cost for the road user in case of the accident. The analysis is capable dedicate that the project has a positive NPV, IRR is greater than the social discount rate and the project is economically feasible and approved. From what reason above, the team proposed implications for managers in improving investment efficiency. 
International Journal of Business Management and Economic Review

Vol. 3, No. 02; 2020

ISSN: 2581-4664

\section{REFERENCES}

1.Boardman, Greenberg, D., Vining, A., Weimer (1996). Cost - Benefit analysis: Concepts and Practice - second edition. Prenice Hall. New York. Chapter 1.

2.Boardman, N. E. (2006). Cost-benefit Analysis: Concepts and Practice (3rd ed.). Upper.

3.Saddle River, NJ: Prentice Hall; Cellini, Stephanie Riegg; Kee, James Edwin. "CostEffectiveness and Cost-Benefit Analysis" . Archived from the original on 2013-05-26. Retrieved 2012-09-24.

4.Đuc Binh, The average income of employees in 2018 is 5.5 million / month, Internet: https://bom.to/Fmy9m3, Retrieved on 24/10/2019.

5.Frank, Murray; Shen, Tao (2012). "Investment, Q, and the Weighted Average Cost of Capital". Social Science Research Network.

6.General light system on the nternet: https://bom.to/GY667E, Retrieved on 24/10/2019.

7.Law on Road Traffic (2008), No: 23/2008/QH12.

8. World Bank East asia and pacific economic update 2011 \& IMF, World economic outlook, $07 / 2010$. 